\title{
GIS-Based multi-criteria decision making model for site selection of seaweed farming information centre: A lesson from small islands, Indonesia
}

\author{
Wellem Anselmus Teniwut ${ }^{a^{*}}$, Marimin $^{\mathrm{b}}$ and Taufik Djatna ${ }^{\mathrm{b}}$
}

${ }^{a}$ Fisheries Agribusiness Study Program, Tual State Fisheries Polytechnic, Langgur, Southeast Maluku, Indonesia

${ }^{b}$ Department of Agroindustrial Technology, Faculty of Agricultural Technology, Bogor Agricultural University, Bogor, West Java, Indonesia

\begin{tabular}{l}
\hline C H R O N I C L E \\
\hline Article history: \\
Received July 3, 2018 \\
Received in revised format: \\
July 10, 2018 \\
Accepted August 2, 2018 \\
Available online \\
August 2, 2018 \\
\hline Keywords: \\
Seaweed farming \\
Small islands \\
Information centre \\
Site selection \\
GIS-MCDM
\end{tabular}

\begin{abstract}
A B S T R A C T
Seaweed had proven to become a fisheries commodity to provide a significant multiplier economic effect for coastal community in Southeast Maluku District during 2005-2013. However, the declining on the productivity of seaweed has given a direct impact on welfare of farmers and coastal communities in this region during the recent years, due to asymmetric information on seaweed farming associated with prices, latest technology and all pre and post production activities. Thus, forming a dedicated information centre for seaweed farming in the region has become a necessity. As small island regions, in Southeast Maluku district, farmers and all stakeholder have to deal with cliché problems such as insufficient infrastructure, lack of transportation, farmers locations that spread across the islands. This paper focused on the selection of suitable location for the information centre for seaweed farming in Southeast Maluku district, Indonesia. Analytical hierarchy process (AHP), in classical and fuzzy forms, was an approach used on this study for suitability analysis. Moreover, GIS for spatial analysis in addition to AHP was used to compare the best results for the location of information centre for seaweed farmers. The results show that fuzzy AHP could provide more suitability location compared with conventional AHP. Most of suitability locations were located in three sub-districts regions and also most of them were located in Kei Kecil Island and Kei Besar Islands due to the geographical characteristics of the region. The sensitivity analysis was conducted to measure the sensitivity of the results when the weight of each criterion was changed. The outcome of this study was to serve its purpose as an input and comparison study for a recent local government of Southeast Maluku' policy on developing seaweed farming in this region.
\end{abstract}

C 2018 by the authors; licensee Growing Science, Canada.

\section{Introduction}

The role of information for the success of any kind of business such as small business is significantly high (Vaughan, 1999), despite the change of information technology has shifted the behaviour of people (Lyu \& Hwang, 2014), but the condition still cannot be applied to all regions in the world. In small islands region especially in Indonesia, access of internet and the knowledge of using search engine is not as much as the people who live in urban and big cities, which can affect the productivity of coastal community' daily activities includes fisheries. As evidence in Southeast Maluku District, where seaweed farmers struggled to maintain their productivity in recent years due to asymmetric information related to seaweed farming supply chain (Teniwut, et al., 2017a). Therefore, it is crucial to improve the

* Corresponding author.

E-mail address: wateniwut@polikant.ac.id (W. A. Teniwut)

(C) 2019 by the authors; licensee Growing Science, Canada. doi: $10.5267 /$ j.dsl.2018.8.001 
information flow among seaweed farmer in the region. In general, seaweed farming offers favourable features in terms of easiness to conduct and also economic multiplier impact on marginal coastal community, compared with other fisheries activities; namely fishing, crabs and grouper cultivation (Hurtado-Ponce et al., 1996). Since seaweed has proven to contribute the higher multiplier boost for local economic, local government of Southeast Maluku district which has decided to make seaweed as one of region' top commodity, in 2017, local government has decided to put seaweed in their Regional Medium-Term Development Plan for 2017-2022.

As archipelagic region which consists of many small islands, Southeast Maluku has a great advantage in particular in environmental support to meet all the requirements for seaweed cultivation. As small islands are surrounded by sea, this makes the region to be broadly coastal zone, which contains vegetation, energy, minerals and biology as the major source for many sea creatures includes seaweed (Chunye \& Delu, 2017). In addition to its natural support, the potential impact welfare of coastal community makes seaweed cultivation becomes an obvious choice to be major sources of income. During the span of 7-8 years, the contribution of seaweed for the development of local economy had greatly presented but since 2013 the number of farming have declined gradually because of pest and diseases, price instability, lack of the availability of seaweed' seeds and access to technology (Teniwut \& Kabalmay, 2015). Thus, it is necessary to form an information centre for seaweed cultivation that will act as a hub to connect farmers to information on the latest technology and knowledge, information on the market condition related to demand and selling price also helping farmer to deal with technical problem on seaweed farming. The information centre can provide services also support the needs of the user on their related activities (Essex et al., 1998). Because of the geographical conditions, which consist of small islands added with the lack of sufficient infrastructures, road accessibility and transportation on this region, it is relatively hard to select the exact and accurate location for the information centre.

To date, GIS-based suitability analysis has been commonly used for site selection, where this approach, in general, is an analysis on layers that contains spatial data to evaluate and select particular area based on its suitability criteria classified according to certain measures and processes (Malczewski, 2006b; Malczewski \& Rinner, 2015). The applications of GIS-based suitability analysis for site selection have widely applied for marine and fisheries field and also in other fields, likes in site selection for marine fish cage (Pérez et al., 2003); sustainability aquaculture management area (Longdill et al., 2008); mangrove oyster raft culture (Buitrago et al., 2005); selfish aquaculture (Silva et al., 2011); offshore marine fish farm (Dapueto et al., 2015); artificial reefs (Mousavi et al., 2015); industrial area (Rikalovic et al., 2014); industrial wastewater discharge in coastal regions (Li et al., 2017); wind farms (Villacreses et al., 2017). Although as it has found on previous studies, there was a limited number of studies on marine and fisheries sector especially in selecting specific areas of inland. Furthermore, the combination of GIS and multiple criteria decision making (MCDM) can bring greater advantage on the strengthening of the result on suitability analysis, GIS can provide support on solving spatial problem (Malczewski, 2006a) and combine with tools in MCDM namely analytical hierarchy process (AHP) can provide organized construct on selecting the effective solution based on different criteria (Marimin, 2005). In addition, to overcome the uncertainty on AHP, fuzzy logic has been used by researcher along with AHP method known as fuzzy AHP (FAHP) (Sun, 2010). The implementation of GIS-based MCDM especially with AHP or FAHP widely has been applied by researchers (Mosadeghi et al., 2015; Pourghasemi et al., 2012; Zhang et al., 2015). Despite the number of researchers to use MCDM along with spatial analysis, there was only smaller number of studies to use, at least, more than one MCDM tools, for instance, AHP and FAHP, or ANP and VIKOR, etc. There also combination of GIS and MCDM to rank the best criteria which are either explicit or implicit characteristics (Malczewski, 2006a). In this study criteria used for suitability analysis for information centre on seaweed cultivation are used in GIS application to select the efficient alternative for site location, (Feizizadeh \& Blaschke, 2013). In this study, we conside different criteria for information centre for seaweed cultivation namely; slope, road access, village distance, number of seaweed farmers in each sub-district in GIS application. 
AHP and fuzzy AHP are used to rank the weight of each criterion on suitability location for information centre for seaweed cultivation. In this study, we also consider uncertainty for different criteria.

This paper focuses on conducting spatial analysis with AHP and fuzzy AHP (FAHP) approaches on selecting the most suitable location for information centre for seaweed cultivation in Southeast Maluku district, Indonesia. The combination of GIS with AHP and FAHP can provide powerful and better results for information centre for seaweed cultivation site selection. Furthermore, the composition of the rest of this paper is as follows, section 2 includes material and method. Section 3 provides the results of this study, discusses the restriction model, suitability model and final parcel selection for suitability. In Section 4 we discuss of the results and continue with section 5, where conclusion and future implication are discussed.

\section{Material and Method}

\subsection{Study Location}

Indonesia is considered as the largest archipelago country in the world, with over 18,100 islands and estimated over $60 \%$ of its people live in small islands region (CTI-CFF, 2009). The study location is part of Kei Islands, located in Southeast of Maluku Province in the eastern part of Indonesia. Southeast Maluku geographically is located in $5^{\circ}$ to $6,5^{\circ}$ south latitude and $131^{\circ}$ to $133,5^{\circ}$ east longitude, this region consists of two largest islands (larger island and smaller island) added with 25 small islands spread along the area (Fig. 1). The centre of local government and economy activity is located in smaller islands, thus, the infrastructure and road access are significantly better than larger islands. This region covers more than $\pm 7.856,70 \mathrm{~km}^{2}$ where almost half of this region is water at $\pm 3.180,70 \mathrm{~km}^{2}$ and land area is $\pm 4.676,00 \mathrm{~km}^{2}$. This region is located in average $\pm 100 \mathrm{~m}$ to $115 \mathrm{~m}$ below sea level, as reported in 2016, the population of Southeast Maluku district was 98.684, where the population density of Southeast Maluku district in 2016 reached 95.64 people $/ \mathrm{km}^{2}$ (Statistic Indonesia, 2017). There are 11 sub-districts in this region, six sub-districts is located on smaller Kei island (Kei Kecil) and five subdistricts on larger Kei island (Kei Besar) to cover a total of 191 villages. Southeast Maluku has several famous marine tourism destination location in the country namely pasir panjang and ngurmunwatwahan beaches in Ngilngof Village and Ohoidertutu Village, sandbar in Warbal Village and coral reefs views. Most of the community in this regions rely on fisheries and marine sector such as fishing and mariculture (pearl, grouper and seaweed), some of the community members also rely on agriculture sector for major source of income. As overall fisheries sector gives the largest contribution on district regional growth domestic product (GDP). In 2016, the number of fishermen were 5.620 compared with the number of mariculture farmers at 4.652 (Statistic Indonesia, 2017). The productivity of mariculture largely was contributed by seaweed cultivation at $6.455,70$ ton in 2017 contributed to IDR 38.734.202.000,- in 2017 (Marine and Fisheries Office of Southeast Maluku District, 2017).
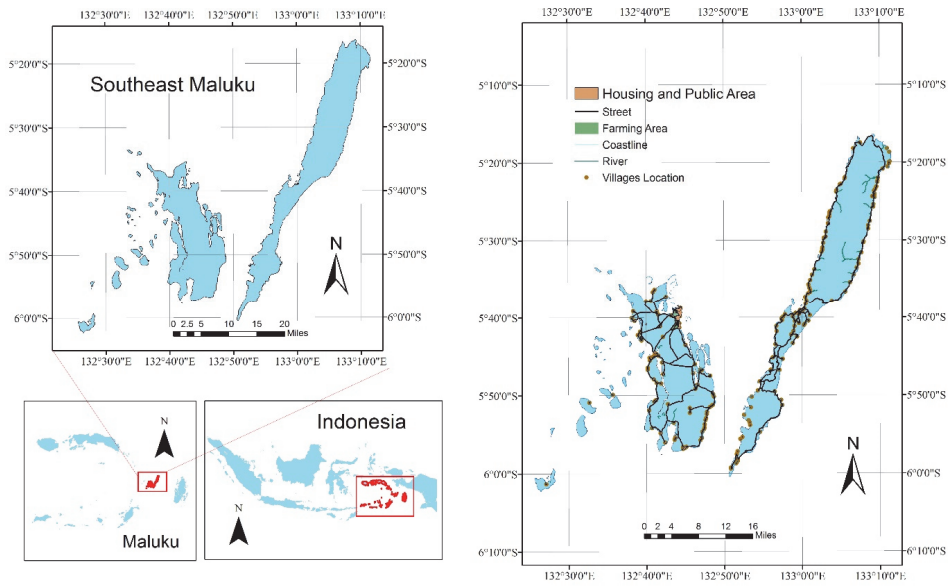

Fig. 1. Study Location 


\subsection{Method}

The framework of this study is illustrated in Fig 2, which is in two parts.

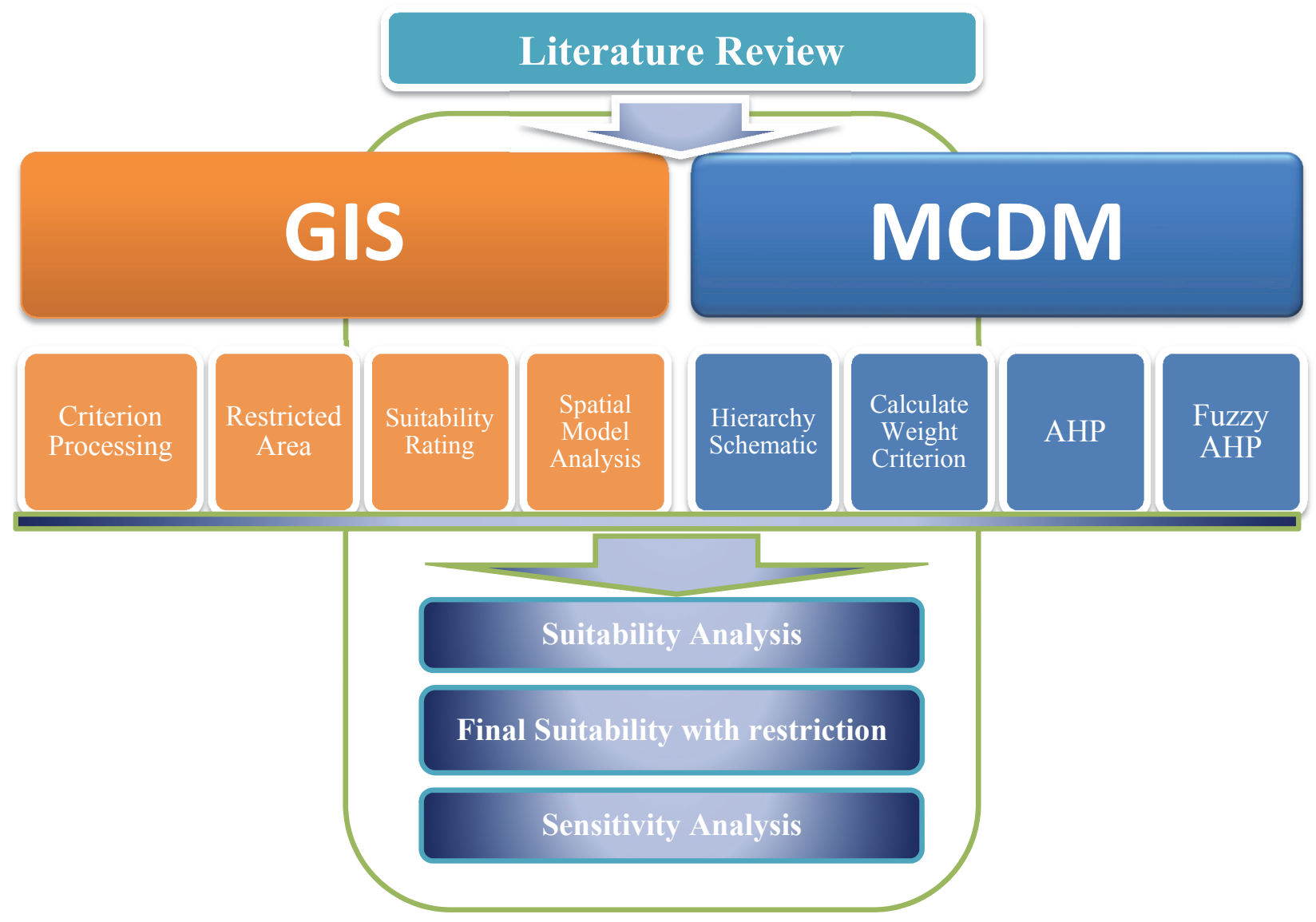

Fig. 2. Study Framework

One part uses ESRI ArcGIS 10.4 to process the data related to spatial analysis, and for the processing of the other part of the study, which is based on the implementation of MCDM, Microsoft Excel was used to calculate the weights for all criteria both for AHP and fuzzy AHP. By combining these two approaches, we obtain the suitability parcel location and also sensitivity analysis.

\subsubsection{Evaluation criteria}

For the decision-making process, the use of multi-criteria decision making becomes a common thing in order to select the best alternative that coexistence in many types of criteria (Al Garni \& Awasthi, 2017). There are two stages in this study for the evaluation of each criterion for selecting the final parcel for information center for seaweed cultivation locations. The first stage: identification and selection of the possible criteria; namely distance from the road, distance from each village, slope and number of seaweed farmers from each sub-district which are accomplished using MCDM technique. When we choose criteria in this study, we based our model from two conditions, first was the characteristics of the study area and input from the previous studies, where researchers always include slope as one the mandatory criteria for suitability analysis (Şener et al., 2010; Van Haaren \& Fthenakis, 2011; Vasiljević et al., 2012), distance from certain location and road access (Rikalovic et al., 2014; Hadipour et al., 2015; Ahmadisharaf et al., 2016; Bunruamkaew and Murayam, 2011; Azizi et al., 2014) and density of population (Vlachopoulou et al., 2001; Longdill, et al., 2008) and in this study this is the number of seaweed farmers in each sub-district. In second stage we calculate the weights of different criteria to obtain the final ranking of all criteria. For prioritizing each criterion this study uses three categories of experts. First; practitioners, in this case, they are farmers and distributors of seaweed in the region. Second: academician, where in this study, researcher and lecturer with expertise in information and 
communication also marketing communication are considered. Third: bureaucrats and this was the head of marine culture division on Marine and fisheries office of Southeast Maluku District. These experts were asked to give their perceptions on ranking the importance of criteria based on their experiences and areas of expertise. For the ranking, AHP is used where intermediate values are "Perfect," "Absolute," "Very good," "Fairly good," “Good," "Preferable," “Not Bad," "Weak advantage” and "Equal", in adjustment to fuzzy AHP, the following fuzzy numbers in this study are used (Gumus, 2009) presented in Table 1.

\section{Table 1}

Fuzzy membership numbers

\begin{tabular}{lcll}
\hline Linguistic Term & Scale of Fuzzy Number & Linguistic Term & Scale of Fuzzy Number \\
\hline Perfect & $(8,9,10)$ & Preferable & $(3,4,5)$ \\
Absolute & $(7,8,9)$ & Not Bad & $(2,3,4)$ \\
Very Good & $(6,7,8)$ & Weak Advantage & $(1,2,3)$ \\
Fairly Good & $(5,6,7)$ & Equal & $(1,1,1)$ \\
Good & $(4,5,6)$ & & \\
\hline
\end{tabular}

Furthermore, to carry the fuzzy AHP analysis we used the approach by Sun (2010), where there are two steps in fuzzy AHP analysis. Step 1: Pairwise comparison matrix on all criteria by asking which criteria is more important, as shown below matrix $\tilde{A}$ :

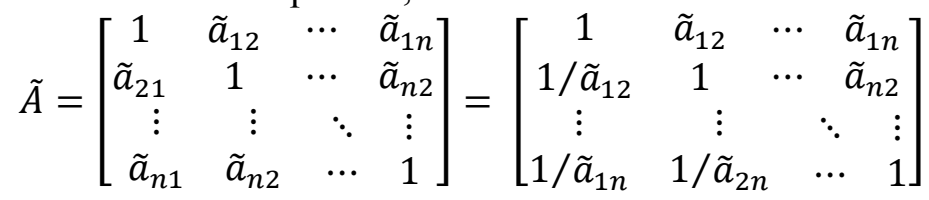

where

$\bar{a}_{i j}=\left\{\begin{array}{rr}\widetilde{9}^{-1}, \widetilde{8}^{-1}, \tilde{7}^{-1}, \tilde{6}^{-1}, \tilde{5}^{-1}, \widetilde{4}^{-1}, \widetilde{3}^{-1}, \widetilde{2}^{-1}, \tilde{1}^{-1}, \widetilde{1}, \widetilde{2}, \widetilde{3}, \widetilde{4}, \widetilde{5}, \widetilde{6}, \widetilde{7}, \widetilde{8}, \widetilde{9} & i \neq j \\ 1 & i=j\end{array}\right.$

Step 2: To define fuzzy geometric mean and fuzzy weights of each criterion, we use geometric mean (Hsieh et al., 2004)

$$
\begin{aligned}
& \tilde{r}_{i}=\left(\tilde{a}_{i 1} \otimes \ldots \otimes \tilde{a}_{i j} \otimes \ldots \otimes \tilde{a}_{i n}\right)^{1 / n}, \\
& \widetilde{w}_{i}=\tilde{r}_{i}\left[\tilde{r}_{i} \otimes \ldots \otimes \tilde{r}_{i} \otimes \ldots \otimes \tilde{r}_{n}\right]^{-1},
\end{aligned}
$$

where, $\bar{a}_{i n}$ is fuzzy comparison value of criterion $i$ to criterion $n$, thus, $\tilde{r}_{i}$ is geometric mean of fuzzy comparison criterion $i$ to each criterion, $\widetilde{w}_{i}$ is the fuzzy weight of the $i$ th criterion, indicated by TFN, $\widetilde{w}_{i}=\left(L w_{1}, M w_{1}, U w_{1}\right)$. Also, $L w_{1}$ is lower value, $M w_{1}$ is middle value and $U w_{1}$ represents upper value of fuzzy weight of the $i$ th criterion. The consistency on matrix we used is the standard consistency ratio $(\mathrm{CR})$ as follows,

$$
C R=\frac{C I}{R I}
$$

where RI is random index and CI is consistency index. In addition to determining CI, we used the following equation:

$$
C I=\frac{\lambda_{\max }-n}{n-1}
$$

where $\lambda_{\text {max }}$ is the maximum value of eigenvector; $n$ is the number of criteria. Value of CR is acceptable when CR below 0.1 (Saaty, 1980).

\subsubsection{Define and rank suitability criteria}

For the determination of suitability for each criterion, literature study is combined with a preliminary field study to obtain a comprehensive information about the recent conditions of this region. For 
distance from each village criteria, as previous studies showed that the location of information center should be near with each village, but we have to also consider the social-economic conditions in this region where the potential conflict between villages tends to be destructive as Teniwut et al., (2017b) and Yamazaki, et al. (2018) stated, conflict in coastal community either intra or inter villages in this region was a possibility. Therefore, for the distance from the village, $5 \mathrm{Km}$ from each village is considered as the highest suitability and below $1 \mathrm{~km}$ was considered as the least suitability. We obtained data for distance from village from board of research of Southeast Maluku district. For other criteria, namely slope, the higher ground represents the least suitability and we obtained the slope from USGS. Distance from the street, the nearest is the highest suitability, data were obtained from the board of research of Southeast Maluku district. For the number of seaweed farmers in each sub-districts, the more farmer in each sub-district, the higher suitability and the necessary data were obtained from Marine and Fisheries Office of Southeast Maluku District. Five suitability ranking was used in this study, where 1 represented the least suitability and 5 was the most suitability (Fig 3). In this study, suitability index was used based on linear combination model (Zhang et al., 2015), with an addition of multiplication of sum of restrictions in the model, which can be seen as follows,

$$
S=\sum_{i=1}^{n} W_{i} C_{i} \prod_{j=1}^{m} r_{j}
$$

where $n$ is the number of criteria, $W_{i} C_{i}$ is the weight of each criterion which is based on AHP. In the study, we used four criteria (Fig 3) and fuzzy AHP calculation and $r_{j}$ represents the restrictions, where in this study we used six restrictions (Fig 3).

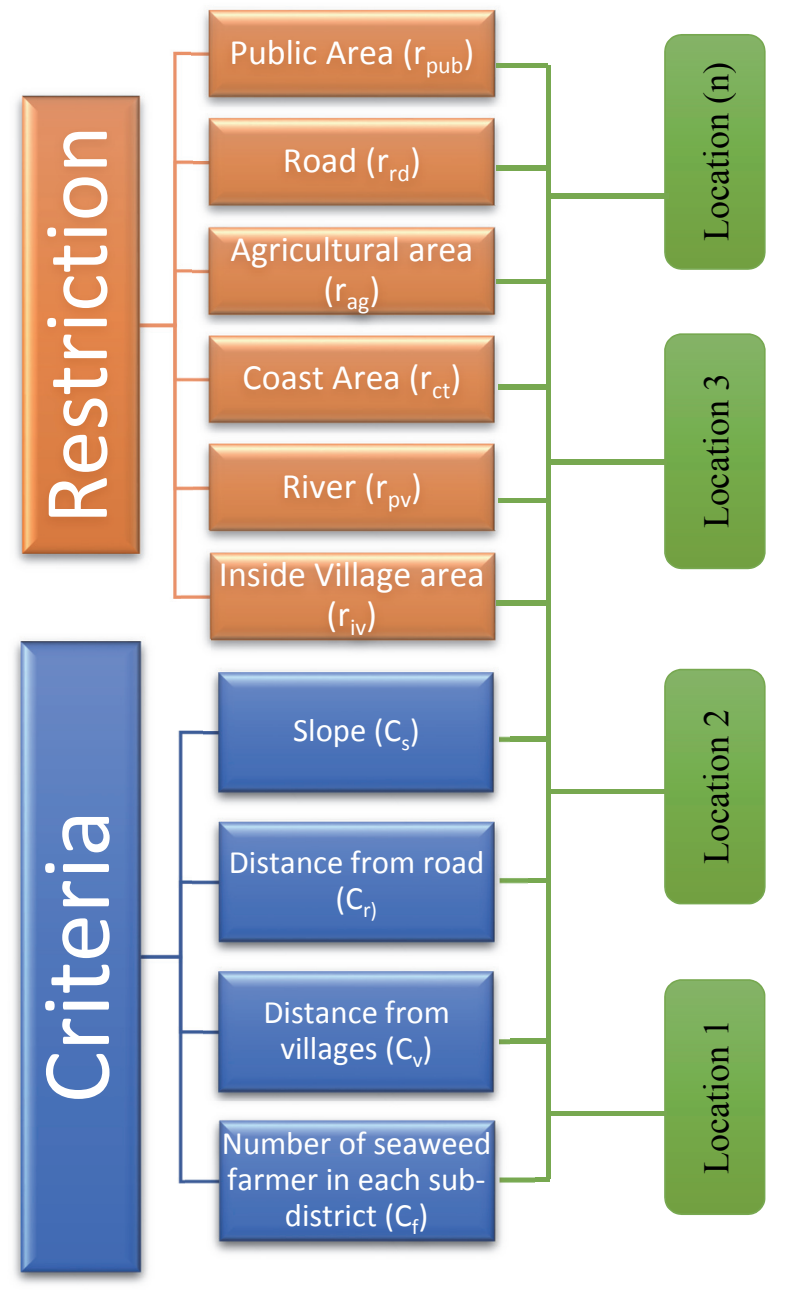

Fig. 3. Hierarchy decision criteria and restriction for information centre for seaweed cultivation 
The expanded equations of Eq. (5) are as follows,

$$
\begin{aligned}
& S=\left(W_{s} C_{s} \cdot W_{r} C_{r} \cdot W_{v} C_{v} \cdot W_{f} C_{f}\right) \prod_{j=1}^{m} r_{j} \\
& S=\sum_{i=1}^{n} W_{i} C_{i}\left(r_{p u b} \cdot r_{r d} \cdot r_{A g} \cdot r_{c t} \cdot r_{r v} \cdot r_{i v}\right)
\end{aligned}
$$

\subsubsection{Restriction Area}

In selecting the location for information center for seaweed cultivation in Southeast Maluku district, there is an area that has been occupied with other activities such as agricultural farming, public places and housing, therefore, those areas have to be excluded from the information center for seaweed cultivation location. In addition, areas also may be restricted by other issues; namely coast area, road, rivers, etc. In particular for inside village areas were added to the restricted location in regard to the sociology factor of an indigenous community in Southeast Maluku District. Indigenous practice that might have impacted the information center is the practice of "Sasi". In addition to the risk of conflict among community most of the time followed by the practice of Sasi which is temporal prohibited to enter certain location area that belong to particular family or village because of cursing, slander, arguing, fighting, harassing (Thorburn, 2000), thus it is necessary to exclude village area for information center for seaweed cultivation. Although Sasi rarely to last more than two months unless Sasi for prohibiting on harvesting crops, marine resources which increase the time more than half a year. As a result of restriction, Fig. 4 shows the selection of the information centre for seaweed, cultivation location, where black areas are restriction areas and green areas are the available locations.

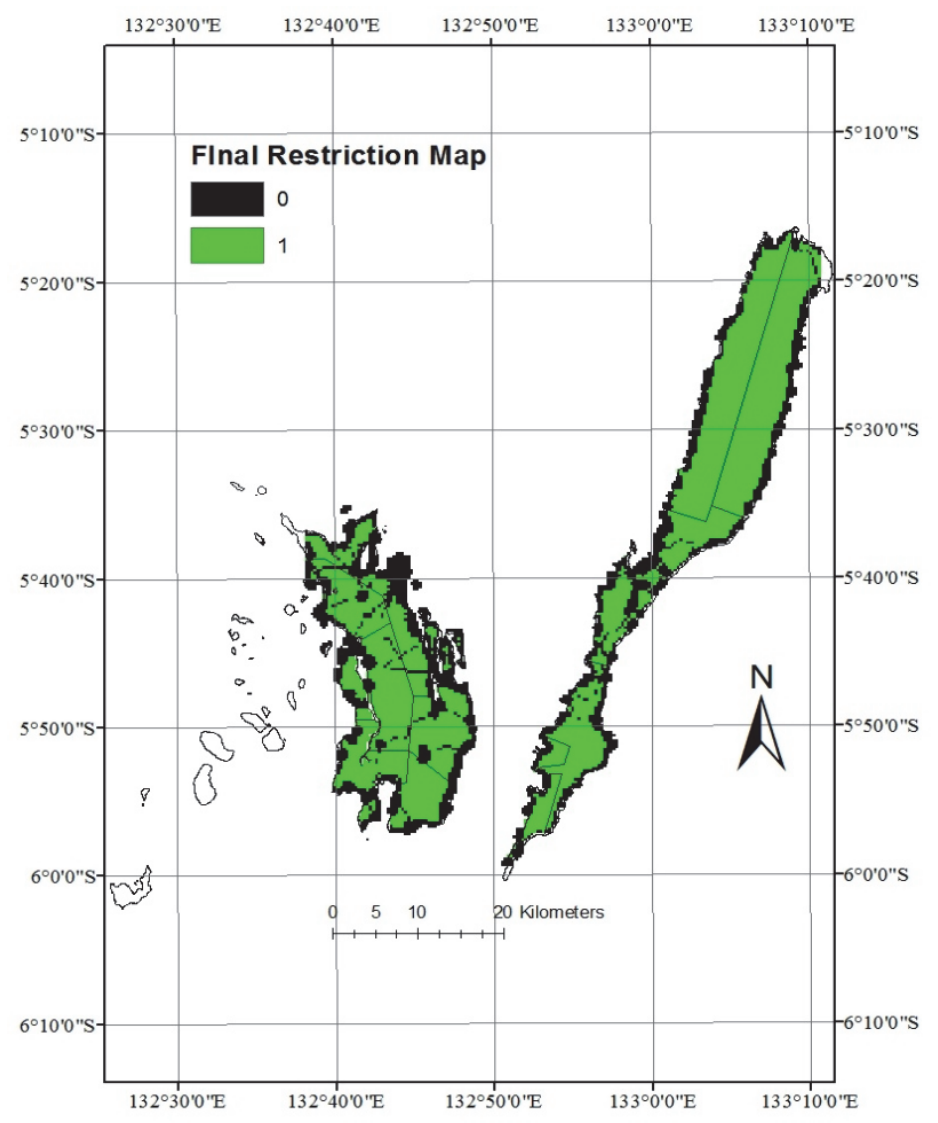

Fig. 4. Final restriction map 


\section{Result}

\subsection{AHP and Fuzzy AHP Spatial Analysis Comparison}

The outcome of calculating the weight for each criterion is based on both AHP and fuzzy AHP represented in Table 2 and Fig 5. The consistency ratios for both AHP and fuzzy AHP are also below threshold of $10 \%$, where CR for AHP and FAHP were 0.07 and 0.09 respectively, therefore the adjustment matrix were consistent. Fig 5 shows the classification of each criterion, where Euclidean distance was used to classify the range of suitability for distance from road and distance from villages. Where on all illustrated criteria, blue colour represents the higher rank of each criterion and light yellow represents the least suitability grade. In Table 2, we can see the weight ratio of each criterion for the site selection information centre for seaweed farming for AHP and Fuzzy AHP. As we can see both AHP and Fuzzy AHP place the number of seaweed farmer in each sub-districts as the most important criterion of 0.59 for AHP and 0.63 Fuzzy AHP, respectively followed by distance from road of 0.26 for AHP and 0.24 for AHP fuzzy; Distance from Villages of 0.10 for AHP and 0.09 for fuzzy AHP and slope of 0.06 for AHP and fuzzy AHP, respectively.

Final results for suitability model based on AHP and FAHP with no restriction are shown in Fig 6. Suitability location is based on AHP spatial analysis reveals that $12.4 \%$ of total observed locations are the most suitable area accounted for $10.184 \mathrm{Ha}$ spread mostly in three sub-districts. When comparing the suitability location with spatial analysis based on fuzzy AHP, $12.3 \%$ of the observed area is the most suitability location for information centre for seaweed cultivation accounted for 11.716 Ha. Furthermore, the final suitability location parcels with restriction area to consider is showed in Fig 7. The result stated that for AHP based spatial analysis, $3.890 \mathrm{Ha}$ area is considered as the most suitable for the location information centre for seaweed cultivation, whereas for fuzzy AHP based spatial analysis, $4.592 \mathrm{Ha}$ area is the most suitable area for information centre for seaweed cultivation in this region.

\section{Table 2}

Grading and Evaluation Criterion Suitability

\begin{tabular}{|c|c|c|c|c|}
\hline Criterion & Classification & Grade & $\begin{array}{c}\text { Weight } \\
\text { AHP }\end{array}$ & $\begin{array}{c}\text { Weight Fuzzy } \\
\text { AHP }\end{array}$ \\
\hline \multirow[t]{5}{*}{ Slope } & Very High & $3.50 m-26.65 m$ & \multirow{5}{*}{0.06} & \multirow{5}{*}{0.06} \\
\hline & High & $26.65 \mathrm{~m}-49.81 \mathrm{~m}$ & & \\
\hline & Moderate & $49.81 \mathrm{~m}-135.85 \mathrm{~m}$ & & \\
\hline & Low & $135.85 \mathrm{~m}-293.85 \mathrm{~m}$ & & \\
\hline & Very Low & $293.85 \mathrm{~m}-741.56 \mathrm{~m}$ & & \\
\hline \multirow[t]{5}{*}{ Distance from road } & Very High & $0-466 \mathrm{~m}$ & \multirow{5}{*}{0.26} & \multirow{5}{*}{0.24} \\
\hline & High & $466 \mathrm{~m}-1.3 \mathrm{Km}$ & & \\
\hline & Moderate & $1.3 \mathrm{Km}-2.4 \mathrm{Km}$ & & \\
\hline & Low & $2.4 \mathrm{Km}-3.7 \mathrm{Km}$ & & \\
\hline & Very Low & $3.7 \mathrm{Km}-5 \mathrm{Km}$ & & \\
\hline \multirow[t]{5}{*}{ Distance from villages } & Very High & $3.8 \mathrm{Km}-5 \mathrm{Km}$ & \multirow{5}{*}{0.10} & \multirow{5}{*}{0.09} \\
\hline & High & $2.7 \mathrm{Km}-3.8 \mathrm{Km}$ & & \\
\hline & Moderate & $2 \mathrm{Km}-2.7 \mathrm{Km}$ & & \\
\hline & Low & $1 \mathrm{Km}-2 \mathrm{Km}$ & & \\
\hline & Very Low & $0-1 \mathrm{Km}$ & & \\
\hline \multirow{5}{*}{$\begin{array}{l}\text { Number of seaweed farmers in } \\
\text { each sub-districts }\end{array}$} & Very High & $>1195$ & \multirow{5}{*}{0.59} & \multirow{5}{*}{0.64} \\
\hline & High & $806-1195$ & & \\
\hline & Moderate & $136-805$ & & \\
\hline & Low & $1-135$ & & \\
\hline & Very Low & 0 & & \\
\hline
\end{tabular}




\subsection{Sensitivity Analysis}

The purpose of the sensitivity analysis in this study was to examine the reliability of suitability locations based on the change of weights of each criterion (Crosetto et al., 2000). In this study there were three approaches to analyse the sensitivity of suitability results based on the change of each criteria. First approach was to give all criteria equal weights (Tegou et al., 2010) and the second approach was to set the highest criteria on both AHP and FAHP with the half of the weight and the other criterion share the rest of the weights equally and the third approach was based on using weights of $\pm 20 \%$ of each criteria (Chen et al., 2010) (Fig 8). The outcome of the sensitivity analysis shows when the weights for all criterion are equal the suitability location are mostly in medium suitability as high as 3 and when the number of seaweed farmers in each sub-district is half of the weight and other criteria share the rest of weight equally there are suitability level as high 4 and as for the weight $\pm 20 \%$ of each criteria, there were some changes on the number of locations with rank 5 . The outcome has indicated that the change of criterion weights in this study sensitively affect the suitability location in the region especially for the most suitable locations.
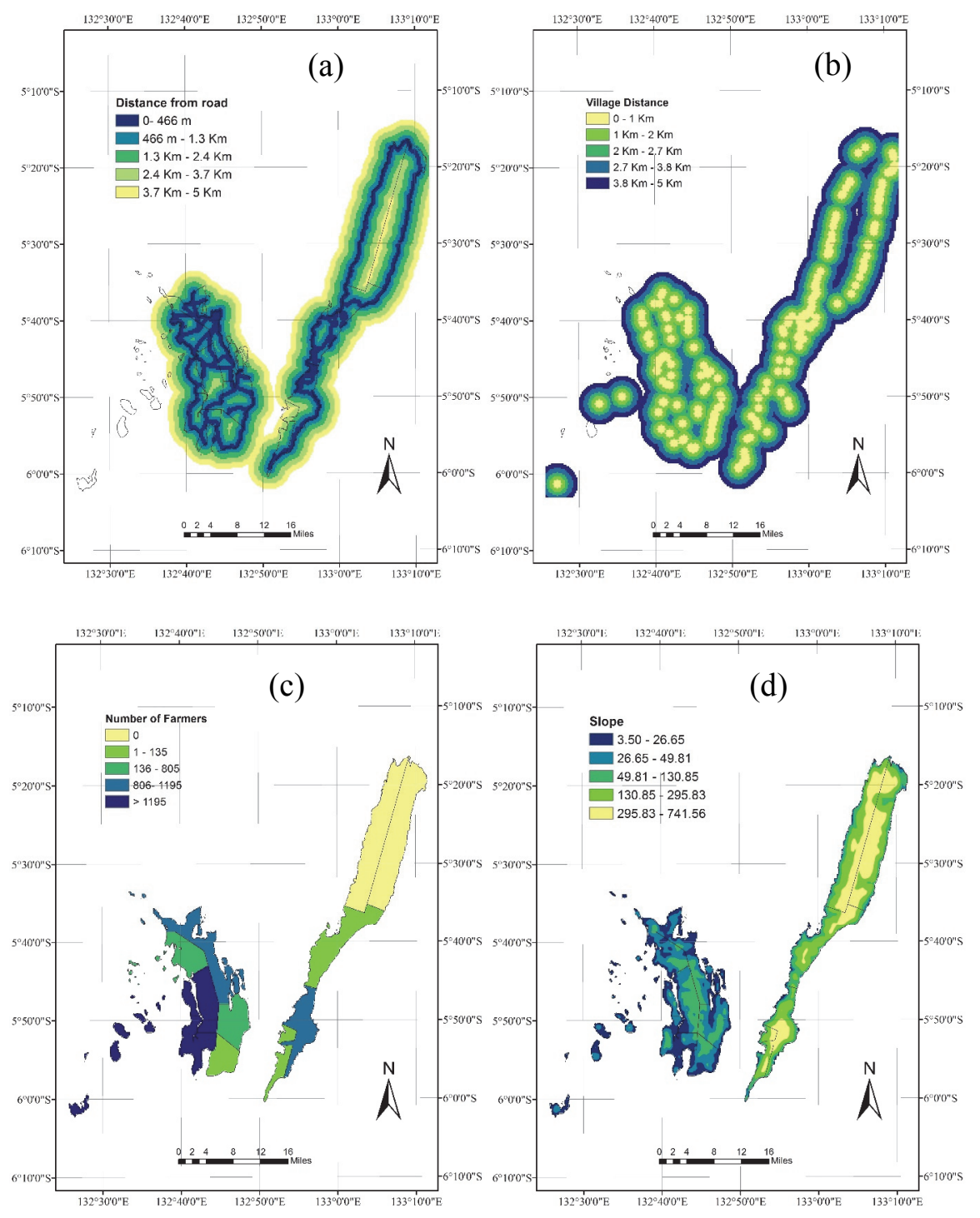

Fig. 5. Suitability Criteria; (a) distance from the road; (b) village distance suitability; (c) suitability map for the number of seaweed farmers in each sub-district; (d) slope suitability 


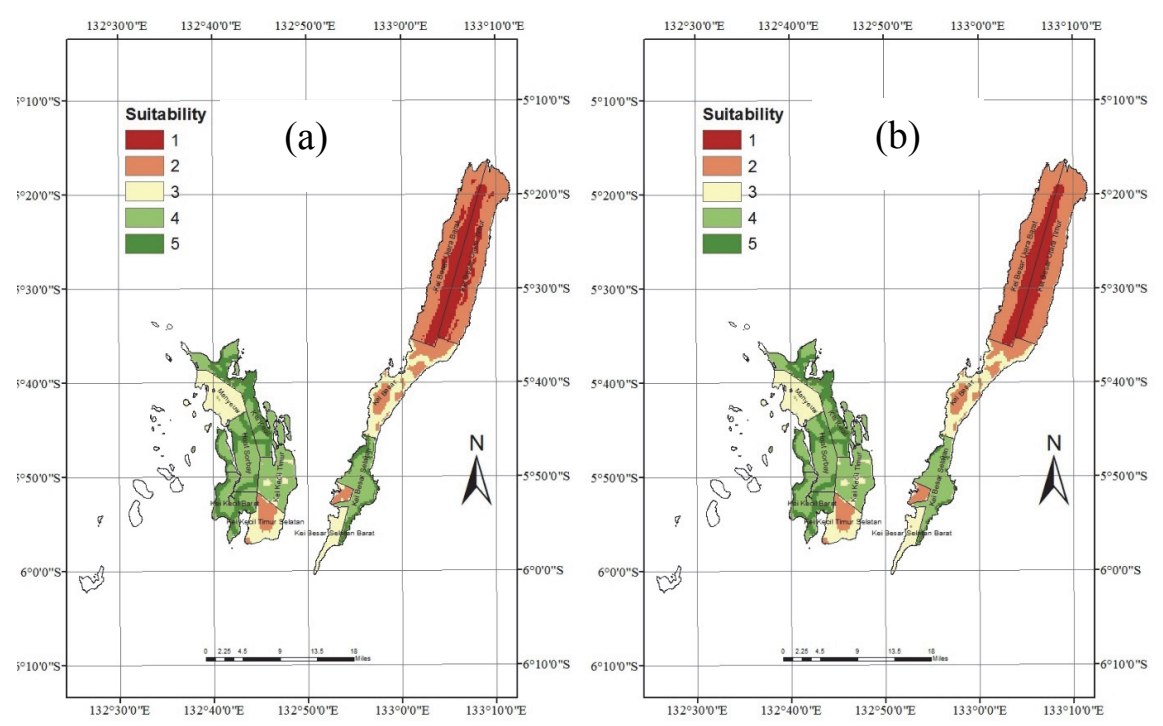

Fig. 6. Suitability with no restriction: (a) Fuzzy AHP; (b) AHP

\section{Discussion}

The application of MCDM in suitability analysis especially for the use of AHP and GIS-based suitability analysis has widely used. Nonetheless, there is a criticism for the use of conventional AHPs in dealing with uncertainty conditions, so the addition of more complex MCDM techniques such as fuzzy logic to conventional AHP becomes necessary (Ardente et al., 2004). Thus, in this study, we have conducted a survey for site selection of information centre for seaweed farming by using conventional AHP and fuzzy AHP methods. Based on the results of suitability analysis with AHP and fuzzy AHP the results have revealed that there were more suitability locations obtained with Fuzzy AHP than traditional AHP. This is due to the contribution of more complex and diverse expert perceptions to each of the criteria calculated with the fuzzy number, which can provide better judgment from experts' judgment which cannot be considered in a conventional AHP (Chen et al., 2011; Ayalew et al., 2005).

The result of suitability analysis identifies 57 suitable locations with AHP and 60 suitable locations with AHP fuzzy for location information centre for seaweed farming. These locations are spread out in five sub-districts namely West Kei Kecil, Hoat Sorbay, Manyeuw, Kei Kecil and West-side of Southern Kei Besar, although most of these were located in three sub-districts namely West Kei Kecil, Hoat Sorbay, Manyeuw and all of these sub-districts were located in Kei Kecil Island due to the high number of seaweed farmers in these areas. In particular, for the Kei Besar Island area, there are only suitable locations in a sub-district which is West-side of Southern Kei Besar. In addition to the number of seaweed farmers in other sub-districts in Kei Besar Island, other factors may cause a minimum number of suitable locations because of the geographical conditions of the region. In the Kei Besar Island, areas are characterized to be more plateau region with mountain and hills which limited the access of transportation, thus the suitability locations for information centre for seaweed farming became very limited. On the other hand in Kei Kecil Island region, aside from more seaweed farmers, the road access contributed to the more suitable location available in this region. Suitable locations that have been obtained in this study have been verified, however, due to many suitable locations, it can adopt an approach as a consideration to select the appropriate point for the information centre for seaweed farming location. The location can be based on two largest islands in the region, where each island will have one information centre. Therefore, there are at least two locations for information centre for seaweed farming; one in each Kei Kecil Island and Kei Besar Island but due to more seaweed farmers in Kei Kecil Island, in addition to one Information Center, local government can add one information centre so can cover all farmers in Kei Kecil Island. 


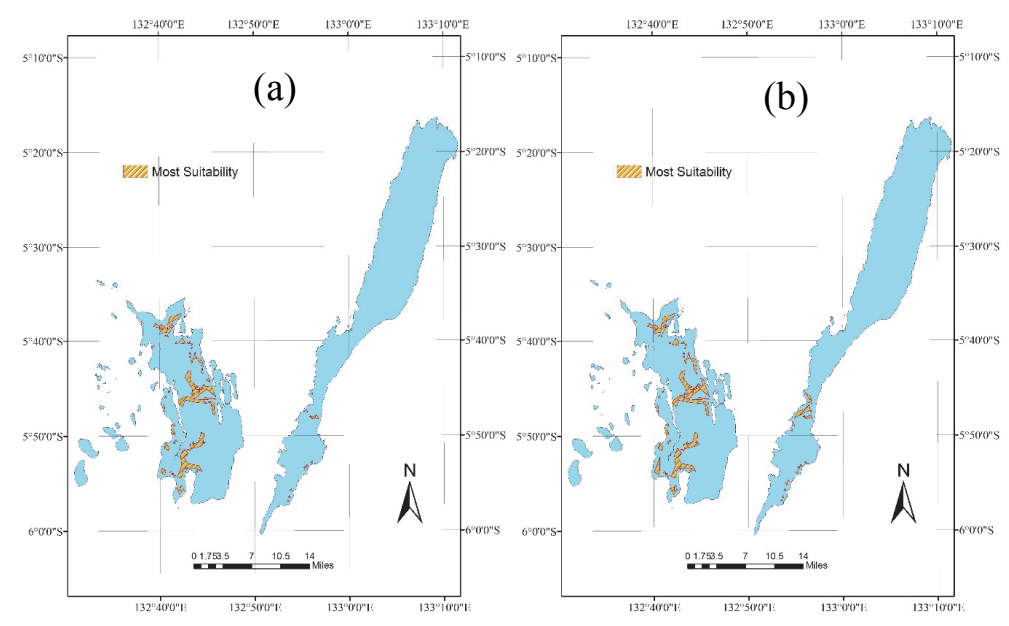

Fig. 7. Suitability parcels with restriction: (a) AHP; (b) Fuzzy AHP
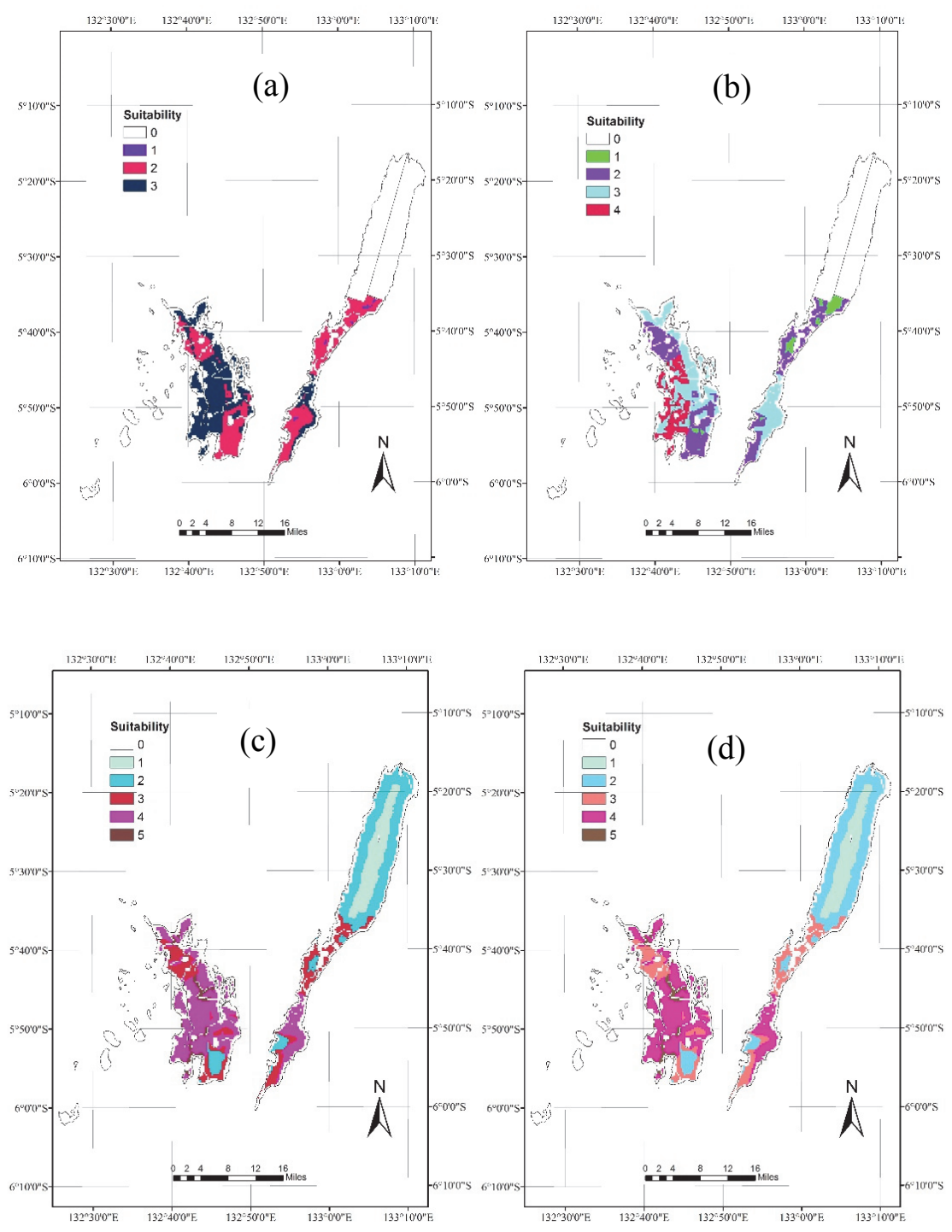

Fig. 8. Sensitivity test: (a) all criterion equal; (b) number of seaweed farmers in each sub-district criteria has half of the weight and other criteria share rest of weight equally; (c) $\pm 20 \%$ of weight for AHP; (d) $\pm 20 \%$ of weight for fuzzy AHP 
The results of this study are expected to serve as a guide for stakeholders, especially the marine and fisheries departments of Southeast Maluku District to overcome the declining of seaweed productivity in this region. In addition, as a comparison to policies that have been done by the local government of Southeast Maluku related to the determination of the location development centre in this region, where local government has chosen to select Arso village located in Hoat Sorbay sub-district, but based on our result, the density of seaweed farmer are spread along the region and that makes local government of this region to address this issue by looking into at least two development points. By doing that, the development of seaweed farming in the region becomes less costly and the flow of information becomes widely access. Further research related to the results of this study may be undertaken, in which the research in selecting the most appropriate location for the location of the information centre for seaweed farming can be done where more multi-criteria decision making (MCDM) portfolio can be applied. Moreover, the addition of more criteria on the future study can also enrich the result, because based on sensitivity analysis on this study, the suitability location can shift from most suitable location with the highest rank of 5 to suitable location with moderate suitable with rank around 3-4.

\section{Conclusion}

This study has shown the effectiveness of spatial analysis especially in the region with many small islands and communities living in the coastal areas by facing some constraints influencing significantly on the daily activities. Suitability analysis with MCDM approach has provided a powerful result for obtaining suitable locations for information centre for seaweed farming by overcoming geographical and infrastructural constraints. Suitability analysis has allowed us to identify the best location accordingly that has an impact on site selection for information centre for seaweed farming while at the same time it could also eliminate restricted areas. The combination of AHP and fuzzy AHP has provided better judgment of each criterion in order to have a better weight of each criterion.

The model can be used by local government to identify location when all the criteria change due to development of the economy, infrastructure and all relevant data. The result of this study identified 5760 suitable locations spread in two largest islands in this region, most of the suitable location was correctly identified. The limitation of this study related to map of villages border, wherein the region up to now has been unable to obtain because there is still disagreement. Therefore, by applying this model with the addition of the number of criteria such as a border of each village and land own by indigenous rules call "petuanan" we can provide better results. The outcome of the study can become an input for local government on developing seaweed agroindustry in the region, especially on their policy on providing an aid either on supply side which is related to latest technology, better knowledge on conducting seaweed farming, which includes dealing with pest and diseases. For demand side also, which is related to provide the market information such as prices and buyers. By doing so, the local government of Southeast Maluku may target to make seaweed as region top commodity in 5 years can be within range.

\section{Acknowledgement}

The authors thank Directorate of Research and Community Service, Ministry of Research and Technology the Higher Education Republic of Indonesia for funding this research in inter-university cooperation research scheme. The authors would also like to thank the marine and fishery office and research boards of Southeast Maluku District in assisting for the collection of data. The result of this study does not represent an official policy of the Southeast Maluku District government and is is solely performed for educational purposes.

\section{References}

Ardente, F., Beccali, M., \& Cellura, M. (2004). FALCADE: a fuzzy software for the energy and environmental balances of products. Ecological Modelling, 176(3-4), 359-379. 
Ahmadisharaf, E., Tajrishy, M., \& Alamdari, N. (2016). Integrating flood hazard into site selection of detention basins using spatial multi-criteria decision-making. Journal of Environmental Planning and Management, 59(8), 13971417.

Al Garni, H. Z., \& Awasthi, A. (2017). Solar PV power plant site selection using a GIS-AHP based approach with application in Saudi Arabia. Applied Energy, 206, 1225-1240.

Ayalew, L., Yamagishi, H., Marui, H., \& Kanno, T. (2005). Landslides in Sado Island of Japan: Part II. GIS-based susceptibility mapping with comparisons of results from two methods and verifications. Engineering Geology, 81(4), 432-445.

Azizi, A., Malekmohammadi, B., Jafari, H. R., Nasiri, H., \& Parsa, V. A. (2014). Land suitability assessment for wind power plant site selection using ANP-DEMATEL in a GIS environment: case study of Ardabil province, Iran. Environmental Monitoring and Assessment, 186(10), 6695-6709.

Buitrago, J., Rada, M., Hernández, H., \& Buitrago, E. (2005). A single-use site selection technique, using GIS, for aquaculture planning: choosing locations for mangrove oyster raft culture in Margarita Island, Venezuela. Environmental Management, 35(5), 544-556.

Bunruamkaew, K., \& Murayam, Y. (2011). Site suitability evaluation for ecotourism using GIS \& AHP: A case study of Surat Thani province, Thailand. Procedia-Social and Behavioral Sciences, 21, 269-278.

Chen, Y., Yu, J., \& Khan, S. (2010). Spatial sensitivity analysis of multi-criteria weights in GIS-based land suitability evaluation. Environmental Modelling \& Software, 25(12), 1582-1591.

Chen, V. Y., Lien, H. P., Liu, C. H., Liou, J. J., Tzeng, G. H., \& Yang, L. S. (2011). Fuzzy MCDM approach for selecting the best environment-watershed plan. Applied Soft Computing, 11(1), 265-275.

Chunye, W., \& Delu, P. (2017). Zoning of Hangzhou Bay ecological red line using GIS-based multi-criteria decision analysis. Ocean \& Coastal Management, 139, 42-50.

Crosetto, M., Tarantola, S., \& Saltelli, A. (2000). Sensitivity and uncertainty analysis in spatial modelling based on GIS. Agriculture, Ecosystems \& Environment, 81(1), 71-79.

CTI-CFF. (2009). Coral Triangle Initiative on Coral Reefs, Fisheries and Food Security: Indonesia National Plan of Action. Jakarta, Coral Triangle Initiative on Coral Reefs, Fisheries and Food Security (CTI-CFF).

Dapueto, G., Massa, F., Costa, S., Cimoli, L., Olivari, E., Chiantore, M., ... \& Povero, P. (2015). A spatial multicriteria evaluation for site selection of offshore marine fish farm in the Ligurian Sea, Italy. Ocean \& Coastal Management, 116, 64-77.

Essex, P. A., Magal, S. R., \& Masteller, D. E. (1998). Determinants of information center success. Journal of Management Information Systems, 15(2), 95-117.

Feizizadeh, B., \& Blaschke, T. (2013). Land suitability analysis for Tabriz County, Iran: a multi-criteria evaluation approach using GIS. Journal of Environmental Planning and Management, 56(1), 1-23.

Gumus, A. T. (2009). Evaluation of hazardous waste transportation firms by using a two step fuzzy-AHP and TOPSIS methodology. Expert Systems with Applications, 36(2), 4067-4074.

Hadipour, A., Vafaie, F., \& Hadipour, V. (2015). Land suitability evaluation for brackish water aquaculture development in coastal area of Hormozgan, Iran. Aquaculture International, 23(1), 329-343.

Hsieh, T. Y., Lu, S. T., \& Tzeng, G. H. (2004). Fuzzy MCDM approach for planning and design tenders selection in public office buildings. International Journal of Project Management, 22(7), 573-584.

Hurtado-Ponce, A. Q., Agbayani, R. F., \& Chavoso, E. A. J. (1996). Economics of cultivating Kappaphycus alvarezii using the fixed-bottom line and hanging-long line methods in Panagatan Cays, Caluya, Antique, Philippines. Journal of Applied Phycology, 8(2), 105-109.

Li, Y., Lin, C., Wang, Y., Gao, X., Xie, T., Hai, R., ... \& Zhang, X. (2017). Multi-criteria evaluation method for site selection of industrial wastewater discharge in coastal regions. Journal of Cleaner Production, 161, $1143-1152$.

Longdill, P. C., Healy, T. R., \& Black, K. P. (2008). An integrated GIS approach for sustainable aquaculture management area site selection. Ocean \& Coastal Management, 51(8-9), 612-624.

Lyu, S. O., \& Hwang, J. (2015). Are the days of tourist information centres gone? Effects of the ubiquitous information environment. Tourism Management, 48, 54-63.

Malczewski, J. (2006a). GIS-based multicriteria decision analysis: a survey of the literature. International Journal of Geographical Information Science, 20(7), 703-726.

Malczewski, J. (2006b). Ordered weighted averaging with fuzzy quantifiers: GIS-based multicriteria evaluation for land-use suitability analysis. International Journal of Applied Earth Observation and Geoinformation, 8(4), 270277.

Malczewski, J., \& Rinner, C. (2015). Multicriteria Decision Analysis in Geographic Information Science. Springer, Berlin.

Marimin (2004). Teknik dan Aplikasi Pengambilan Keputusan Kriteria Majemuk. Jakarta: Grassindo.

Marine and Fisheries Office of Southeast Maluku District (2017). Southeast Maluku Mariculture Report Performance of 2017. Langgur: Southeast Maluku District Office; 2017. 
Mosadeghi, R., Warnken, J., Tomlinson, R., \& Mirfenderesk, H. (2015). Comparison of Fuzzy-AHP and AHP in a spatial multi-criteria decision making model for urban land-use planning. Computers, Environment and Urban Systems, 49, 54-65.

Mousavi, S. H., Danehkar, A., Shokri, M. R., Poorbagher, H., \& Azhdari, D. (2015). Site selection for artificial reefs using a new combine Multi-Criteria Decision-Making (MCDM) tools for coral reefs in the Kish Island-Persian Gulf. Ocean \& Coastal Management, 111, 92-102.

Pérez, O. M., Ross, L. G., Telfer, T. C., \& del Campo Barquin, L. M. (2003). Water quality requirements for marine fish cage site selection in Tenerife (Canary Islands): predictive modelling and analysis using GIS. Aquaculture, 224(1-4), 51-68.

Pourghasemi, H. R., Pradhan, B., \& Gokceoglu, C. (2012). Application of fuzzy logic and analytical hierarchy process (AHP) to landslide susceptibility mapping at Haraz watershed, Iran. Natural Hazards, 63(2), 965-996.

Rikalovic, A., Cosic, I., \& Lazarevic, D. (2014). GIS based multi-criteria analysis for industrial site selection. Procedia Engineering, 69(3), 1054-63.

Saaty, T.L. (1980). The analytic hierarchy process. New York: McGraw-Hill.

Şener, Ş., Şener, E., Nas, B., \& Karagüzel, R. (2010). Combining AHP with GIS for landfill site selection: a case study in the Lake Beyşehir catchment area (Konya, Turkey). Waste Management, 30(11), 2037-2046.

Statistic Indonesia. Southeast Maluku in Number. Langgur: BPS Southeast Maluku Districtl (2017). Retrieved May 6, 2018. Available at: https://malukutenggarakab.bps.go.id/publication/2017/08/11/bb0cdf2c3addd6319fc832c9/kabupaten-malukutenggara-dalam-angka-2017.html.

Sun, C. C. (2010). A performance evaluation model by integrating fuzzy AHP and fuzzy TOPSIS methods. Expert Systems with Applications, 37(12), 7745-7754.

Tegou, L.-I., Polatidis, H., \& Haralambopoulos, D.A. (2010). Environmental management framework for wind farm siting: Methodology and case study. Journal of Environmental Management, 91(11): 2134-2147.

Teniwut, W. A., \& Kabalmay, J. (2015). Empirical study on evaluation of seaweed cultivation in southeast Maluku. In Prosiding Seminar Ilmiah Tahunan (SIT) Ke-2 Politeknik Perikanan Negeri Tual (Vol. 26, pp. 55-60).

Teniwut, W. A., Betaubun, K. D., Marimin \& Djatna, T. (2017a, October). A conceptual mitigation model for asymmetric information of supply chain in seaweed cultivation. In IOP Conference Series: Earth and Environmental Science (Vol. 89, No. 1, p. 012022). IOP Publishing.

Teniwut, W. A., Teniwut, Y. K., Teniwut, R. M., \& Hasyim, C. L. (2017b, October). Family vs Village-Based: Intangible View on the Sustainable of Seaweed Farming. In IOP Conference Series: Earth and Environmental Science (Vol. 89, No. 1, p. 012021). IOP Publishing.

Thorburn, C. C. (2000). Changing customary marine resource management practice and institutions: the case of Sasi Lola in the Kei Islands, Indonesia. World Development, 28(8), 1461-1479.

Van Haaren, R., \& Fthenakis, V. (2011). GIS-based wind farm site selection using spatial multi-criteria analysis (SMCA): Evaluating the case for New York State. Renewable and Sustainable Energy Reviews, 15(7), 3332-3340.

Vasiljević, T. Z., Srdjević, Z., Bajčetić, R., \& Miloradov, M. V. (2012). GIS and the analytic hierarchy process for regional landfill site selection in transitional countries: a case study from Serbia. Environmental Management, 49(2), 445-458.

Vaughan, L. Q. (1999). The contribution of information to business success: A LISREL model analysis of manufacturers in Shanghai. Information Processing \& Management, 35(2), 193-208.

Villacreses, G., Gaona, G., Martínez-Gómez, J., \& Jijón, D. J. (2017). Wind farms suitability location using geographical information system (GIS), based on multi-criteria decision making (MCDM) methods: The case of continental Ecuador. Renewable Energy, 109, 275-286.

Vlachopoulou, M., Silleos, G., \& Manthou, V. (2001). Geographic information systems in warehouse site selection decisions. International Journal of Production Economics, 71(1-3), 205-212.

Yamazaki, S., Resosudarmo, B. P., Girsang, W., \& Hoshino, E. (2018). Intra-village and inter-village resource use conflict in Indonesia: The case of the Kei Islands. Ocean \& Coastal Management, 155, 50-59.

Zhang, J., Su, Y., Wu, J., \& Liang, H. (2015). GIS based land suitability assessment for tobacco production using AHP and fuzzy set in Shandong province of China. Computers and Electronics in Agriculture, 114, $202-211$.

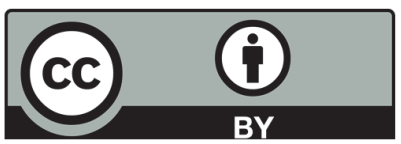

(C) 2019 by the authors; licensee Growing Science, Canada. This is an open access article distributed under the terms and conditions of the Creative Commons Attribution (CC-BY) license (http://creativecommons.org/licenses/by/4.0/). 